\title{
THE PROCESS OF ORGANIZATIONAL RESTRUCTURING OF THE COMPANY IN TERMS OF THE SYSTEM
}

\author{
Henryk DŹWIGOŁ \\ Politechnika Śląska, Wydział Organizacji i Zarządzania; henryk.dzwigol@poczta.fm, \\ ORCID: 0000-0002-2005-0078
}

\begin{abstract}
Purpose: The article presents the methodological requirements of the restructuring program in the context of strategic management and shaping strategic forms. In this case, the enterprise restructuring model is described as the basis for transformations aimed at achieving a knowledge-based organization.
\end{abstract}

Design/methodology/approach: In the research process, the author used the following research methods: literature analysis, analysis of the company's operational documentation, observation, interview, case study.

The author also used extremely important methods commonly used in the general methodology of induction sciences: observations carried out under natural conditions, but the observer is an external person who does not belong to the subject of observation; observations conducted in natural conditions, and the researcher cooperates with the observed situation; observationinterventions that take place as part of transformation activities in organizations.

Findings: The author tries to answer the following question: How should the knowledge management model be perceived in modern companies? In addition, it emphasizes the importance of organizational forms in the process of enterprise restructuring. Therefore, the restructuring process should be carried out based on specific restructuring goals resulting from the scope of change.

Practical implications: The above concept proves that the individual elements of the organizational model are largely complementary. Considering other approaches listed here and related to organization modeling, it should be remembered that in the case of modeling enterprise restructuring processes the scope of modeling is always determined by: specific restructuring goals and the resulting scope of changes in the enterprise; general principles and methodological guidelines regarding organizational changes to be implemented.

Originality/value: The author, using his own experience in enterprise restructuring, has developed a new concept of a systematic approach to the restructuring process on the example of a mining enterprise.

Keywords: methodical requirements, restructuring programme, consolidation criteria. 


\section{Introduction}

The notion of a model generally means a simplified projection of a complex object (Groble, 2006, p. 175). The model arrangement can help to understand its existing and complex stance, i.e. its structure, operation and development. In order to be able to boast any scientific values, the modelling results should be verified by means of a simulation (Sudoł, 2007, pp. 373-374).

As new systems tend to become more and more complex, the systems responsible for their designing have to face ever-growing requirements. Hence, successful enterprises consciously set out to find new designing techniques that would allow shortening the designing process in question and achieve top-quality designing solutions. One essential opportunity in terms of designing is to have recourse to modelling techniques. The essence of modelling lies in presenting a genuine phenomenon in a simplified way. The genuine phenomenon is understood as a scrap of the reality within the scope of existing or future, real physical objects or processes. The model is an abstract pattern, a reflection of a genuine phenomenon achieved by means of ignoring the features that are not a subject of our attention. The model, being a substitute for the genuine phenomenon, is less complex that the reality it tends to reflect. Thus, it is easier to apply models for the scientific or design purposes. The model is therefore a qualitative, quantitative or qualitative and quantitative manifestation of the original phenomenon, which allows patterning and comprehending and examining essential features of interdependencies between researched factors. It is a compromise between striving for faithful representation of a fragment of the researched reality (as regards to taking into consideration the greatest possible number of factors) and its representation possibilities (the more factors a model takes into consideration, the more difficult it is to establish a model, assess it and draw relevant conclusions).

One can notice that the simpler the model is, the more abstract it is. As the model becomes closer to the reality, there appear more and more influence factors, while the model becomes difficult to control. Hence, in order to establish a model, one should apply simplifying assumptions and constraints that will always provoke a discussion on the 'model versus reality' relationship.

The sense of modelling manifests in the fact that a model is more comfortable for examining than a genuine phenomenon, without a need to cover excessive costs. As far as modelling is concerned, two issues are especially significant (Dźwigoł, 2015a):

- the purpose for which a given model is created,

- reciprocal correlations between features of the model and the ones of the genuine phenomenon.

The purpose for which a given model is created determines the model's arrangement and the level of its simplification. While creating a model, we ignore some features for the benefit of putting an emphasis on the others. The purpose of abstracting, perceived as the most essential 
element of modelling, is to separate inessential (as regards to the modelling purpose) features from the essential, i.e. the features that are subject to scientific interest and research. The level of simplification of a genuine phenomenon's features for the benefit of modelling is affected by reciprocal correlations between particular qualities of the said phenomenon.

Still, it cannot be allowed to discard a feature which is strongly correlated with features being researched, since this would result in creation of an incorrect model. Modelling is generally based on the theory of isomorphism, i.e. mutual homogeneity of physically heterogeneous phenomena. It helps to reproduce or represent real phenomena and objects by means of isomorphic models that vary from real occurrences in terms of their physical character. An analogy is a certain kind of correspondence between phenomena. Analogies are used in every field of human activity, including designing. While breaking down a complex research problem into simpler problems, it is often easy to notice an analogy between the current problems and problems which have already been solved, or an analogy between other classes of problems (Dźwigoł, 2015a).

Models are characterised by some specific features that reflect the models' nature. The said features are the following:

- hypothetical character: a model is a 'supposition' that an original, presented in a simplified way, is its adequate representation,

- subjectivism: a model is a representation of an original to the extent determined by needs,

- relative simplicity: a model is a simplification aiming at reducing the number of values contained in the model and dependencies between them, as well as to decrease the form of the dependencies in question,

- diversity: there co-exist various models of the same original destined for different purposes; this co-existence is indispensable as it allows to embody the original from different points of view.

The above-mentioned concept proves that particular elements of the organisational model are complementary to a great extent. Taking into account other approaches mentioned herein and related to the organisation modelling, one should bear in mind that in case of modelling the enterprise's restructuring processes, the scope of modelling is always determined by:

- particular restructuring goals and ensuing scope of changes within the enterprise,

- general principles and methodological guidelines as regards to organisational changes to be implemented (Dźwigoł, 2015b).

In the research process, the author used the following research methods:

- literature analysis,

- analysis of enterprise operational documentation, observation,

- interview,

- case studies. 
The author also employed extremely important methods commonly appplied in the general methodology of induction sciences:

- observations carried out in natural conditions, but the investigating observer is an external person who does not belong to the subject of observation,

- observations conducted in natural conditions, and the researcher cooperates with the observed situation,

- observations-interventions that take place as part of transformation activities in organizations.

This type of activity appears to be privileged in management and quality sciences.

The author, using his own experience in enterprise restructuring, has developed a new concept of a systematic approach to the restructuring process on the example of a mining enterprise (www.scopus.com/...).

\section{Method-related conditions of restructuring programme in the context of strategic management}

Strategic management of the enterprise, under conditions of constant changes, requires reviewing current approaches. One should take into account a few essential issues, namely (Sudoł, 2006, pp. 250-254):

1. Research conducted in the USA and Germany has shown that the necessity for strategic planning is more pressing in bigger enterprises than in smaller ones.

2. To facilitate decision-making processes for managers, certain methods were developed, especially in the USA. The methods in question are used for assessing the attractiveness of particular branches for a given company - they are known as portfolio management methods.

3. Apart from the strategy for a whole company, there is also a need for more detailed strategies for particular activity areas, known as strategic activity areas or strategies of activity profiles - fields or field-related business strategies. Activity-profile strategies refer to independent organisational units within the scope of the activity, which units are regarded as strategic business units.

4. Within the enterprise, there can also occur functional strategies (marketing-related, financial, production-related, personal, product-related, research and development related, etc.).

5. Within the scope of particular functional strategies, there are also substrategies (price strategy, advertisement strategy - for the area of marketing; employees' appraisal strategy - the HR area). 
Nowadays, a strategic reorientation (a strategic shift) is a relatively common occurrence, connected with a revaluation, or even a rejection of the on-going strategy. With reference to the foregoing, there occurs the necessity to develop a new dynamic approach to strategic management that allows formulating a strategy in line with opportunities and innovations (Rokita, 2006, pp. 93-103). Hence, the current concept of strategic planning needs to be supplemented by processes for achieving and maintaining a competitive advantage, by means of a dynamic approach to the strategic management (Carpenter, Sanders, 2007). The question, however, should be posed as to whether strategic planning is feasible under unpredictable future conditions? (Romanowska, 2007, pp. 125-130).

The organisation fluctuates between stability and instability, generating determined but changeable behavioural patterns. In other words, it is on the verge of chaos. Managers have two solutions - either to resign from strategic planning, or to reproduce thinking and behavioural logic from the past. Both solutions are wrong. The process of succeeding does not involve having the right people, appropriate tools or role models, but it does involve having the right strategy - J. Trout (Trout, 2005, p. 11). Today, companies must be able to transform much faster than the environment that surrounds them - Roland Berger. Creating a strategy adjusted to challenges of the $21^{\text {st }}$ century requires taking all necessary actions, namely:

1. To replace development strategies by an activity model or a business model (Slyvotzky, 2000). The solution in question releases managers from their obligation to forecast and make a plan for the entire business activity in an ordered, systematic and systemic way.

2. To shift one's interest from radical choices to emerging strategies and chances. The latter, combined with a perfect organisation and cell-related effectiveness allows the company to adjust quickly to changes.

3. In unpredictable situations, we are looking for a success by means of portfolio restructuring, i.e. through mergers, take-overs and capital alliances.

4. The process of success restoring is perceived as the strategic regeneration skill - which is the ability to introduce changes before the changes become unavoidable. This is a kind of anticipative change (Hamel, Valikangas, 2003, p. 66).

For innovative companies of the $21^{\text {st }}$ century, strategy does not correspond to any formal planning, but to intuition. Strategies are defined but partly, at the intuitive level; they become more elaborate afterwards. Harold Geneen in his work entitled Management offers a perfect illustration of the issue in question: "This is a three-sentence course on business management. You read a book from beginning to end. You run a business the opposite way. You start at the end, and then you do everything you must to reach it". In the assumed situation, i.e. facing the unpredictability of the environment, a question arises which of the following solutions should be employed: 
1. An approach based on a new formula of the planning school, which means searching for a rational way to build a strategy within the difficult environment by means of emphasising the stage of strategic analysis and scenario-based forecasting.

2. A proposal to replace planning techniques by wisdom, expertise and experience that allows indicating seemingly intuitive trends within the enterprise's development. The trend in question is characteristic of the resource school.

The resource-related concept of the strategic management is established on the assumption saying that the management of strategic resources and skills, and their proper application are a key factor for the success of the enterprise. In the unpredictable world, the organisations that make use of their collective wisdom, combined with business research and data collection, are prepared in the best way for changes. Thus, man, his skills and motivation are treated as a strategic ability.

The following dilemmas are therefore to be resolved by managers:

- what approach should be employed to adjust the enterprise to the new reality?

- whether the process of strategic reasoning is either a rational and deductive process or a creative activity requiring imagination?

- whether making of strategic decisions requires either to train managers in procedures pertaining to rational reasoning supported by scientific methods, or to opt for non-conventional creative solutions which intuition suggests? (De Wit, Meyer, 2007).

There is nothing wrong with the fact that the theory of the strategic management is treated as a sack of ideas and conceptions. Perhaps this concept is not attractive from the scientific point of view. Moreover, sticking to it as the only correct approach may be perilous for the enterprise, as within the scope of the strategic management, one has to face a series of uncertainties. Brilliant scientists hold the opinion that one should strive for a new organisational paradigm - perspectives for the development of the strategic management, with an emphasis given to (Dźwigoł, 2015b):

- environmental uncertainty,

- method deficiency,

- information barriers.

One should, thus, seek opportunities for the enterprise's development among its internal factors. Herein, the enterprise is treated as a set of resources and competencies. What is essential is to manage them adroitly. It is necessary, therefore, to develop a new organisational model for the enterprise that would cover rules advocated by researchers and managers, and be used for recognising and describing the organisational reality. The model should also be composed of rules for formulating cognitive and pragmatic methods that can shape competencies and principles for managerial activity. In the operational layer, the restructuring process is formulated by means of a restructuring programme. Premises of the restructuring programme should be developed in consideration of conditions reigning both in the external and internal environment of the enterprise (Dźwigoł, 2015b). 
A strategy is selected in accordance with the enterprise's development pace, its anticipated goals to be achieved and the costs that the enterprise is able to cover. If the enterprise's development pace is rapid, then radical restructuring strategies should be applied. The restructuring programme should include:

- an analysis report and evaluation of the enterprise's strategic situation, along with a diagnosis (Dźwigoł, 2007, pp. 181-190),

- an undertaking's design which is a main document for implementing changes in the enterprise; the design is created at the request of the enterprise's manager,

- a type of a business plan, based on a selected restructuring strategy,

- a vision of the enterprise's future condition, freed from current problems and hazards,

- long-, middle- and short-term action plans, destined to ensure that the vision comes alive.

The restructuring programme can be drawn up by the enterprise's employees - in this case the programme generally lacks radicalism and contains substantive errors, or by external specialists - in that case the programme boasts its higher quality and comprehensiveness, facing at the same time difficulties connected with its implementation, since the enterprise's staff protests against radical changes. Mixed teams consisting of employees and external consultants should be preferred, as this solution:

- will guarantee a suitable substantive level of the restructuring programme and operation of a mixed research-project team,

- will help to convince the enterprise's staff about the necessity of suggested changes.

The structure of every restructuring programme should be based on a root cause of the enterprise's unsatisfactory situation. The programme allows outlining the scope of desired changes (called the subjective scope of restructuring) (Dźwigoł, 2007, p. 80).

\section{Modelling of organisational forms (Dźwigoł, 2015b)}

The model of organisational restructuring, owing to solutions contained therein, essentially responds to modern global challenges, and allows a hard coal mining company to formulate a global strategy and functional strategies (in defined areas), accompanied by solutions which take into consideration ever-changing managing conditions. The model of organisational restructuring is also an instrument applied for a continuous development of the hard coal mining company through, among others, flexible selection of functional areas subjected to organisational restructuring, along with the management support system. An important role is played by the area of informational resources, which, if used effectively, favours identification of opportunities and hazards, supports implementation of strategic management methodology and introduces elements of managerial handling of information - being one of the most essential 
conditions for successful fulfilment of the enterprise's mission and goals, and constituting a considerable element of its non-tangible resources.

\subsection{Model of organisational restructuring as the basis for changes towards knowledge- based organisations}

How should the model of the knowledge management system be perceived in the modern company? Deliberations pertaining to the subject should be initiated by clarifying the notions of intellectual capital and social capital, and by considering their potential influence on the arrangement of the knowledge management model. Intellectual capital includes human relations within the enterprise, that is: cognitive capital (common vocabulary, language and convictions), competencies (knowledge, skills), innovativeness, entrepreneurship and motivation. On the other hand, social capital refers to such social features like trust, standards and bonds that may contribute to the improvement of social competencies through facilitating co-ordinated actions. Like other types of capital, social capital is productive; it allows achieving certain targets which otherwise would not be attainable.

Z. Malara presents the enterprise's learning process in the form of a knowledge loop of an intelligent enterprise. The process in question should take into consideration the occurrence of predictions based on prior experiences, with simultaneous systemising and capitalising of knowledge. Herein, the latter is a foundation for issuing future decisions and actions. Knowledge management is, hence, an effective process of learning being connected with searching for, using and disseminating knowledge (explicit and implicit). The process, employing appropriate technologies and cultural environment, is aimed at enhancing the organisation's intellectual capital and effectiveness (Jashapara, 2006, p. 28). What needs to be underlined is the fact that knowledge management should be of utilitarian character, the latter being understood as a practical approach, closely connected to the effectiveness of knowledge management processes within all areas of the enterprise's activity (Dźwigoł, Wolniak, 2018, pp. 1114-1116). The management in question also determines the level of the enterprise's competitiveness (Kobyłko, Morawski, 2006, p. 7).

Knowledge management is designed to ensure a smooth flow of information and knowledge between all members of the organisation. In numerous papers, the authors enumerate the following positive results (intended as goals of the concept implementation) of putting knowledge management programmes into practice:

- increase in innovations of productive, technological, organisational and corporate character,

- deliberate achievement and exploitation of external sources of knowledge (customers, clients, competitors, co-operators),

- better understanding of customers' needs and expectations,

- anticipation and shaping of customers' needs and expectations, 
- increase in profit as a result of rapid pace of introducing new products and services into the market,

- shortening of manufacturing cycle in terms of state-of-the-art products,

- reinforcement of information bonds between employees (speed, availability, updated information),

- open communication between employees (informal meetings, sharing knowledge and ideas, free and frank discussion, insightful atmosphere),

- enhancement of creativity, provision of opportunities for thinking creatively and formulating bold solutions,

- improvement in speed and quality of decision-making processes,

- reinforcement of information bonds, as well as intellectual and emotional bonds between employees,

- recruitment of employees with great intellectual and professional potential,

- emphasis on continuous education and development of employees,

- more flexible organisational structure (collectivity, lesser formalisation, changeable scopes of tasks and responsibilities, decentralisation of decisions) (Kobyłko, Morawski, 2006, p. 41).

Technical complexity characterising contemporary manufacturing and managing systems entails the need for employees to acquire a higher level of knowledge. The most essential tools for knowledge management include:

- document management systems,

- workflow systems,

- groupware systems,

- intranet - internal communication network using IT tools,

- corporate portals - allow to exchange information,

- data warehouses - easily accessible, comprehensible databases,

- decision-supporting systems, expert systems (Sobczak, Strojny, 2004).

New technologies have contributed to the development of a knowledge-based economy where enterprises more and more often endeavour to create intelligent organisations. The model of the knowledge management system should be a tool supporting the transformation of a learning organisation into an intellectual one (Krzakiewicz, 2007, pp. 131-137). To fulfil it, one should answer the following two questions (Dźwigoł, 2015b):

1. Are we able to predict the continuity of the enterprise's activity and manage our development effectively?

2. Is partial improving of the enterprise effective in the long-term perspective? 
Basic determinants of successful learning within the organisation are the following:

- systems thinking,

- individual professionalism,

- organisational culture,

- development of a general vision,

- group learning (Rolet, 2003).

Currently, one may deal with knowledge process outsourcing, which means the outsourcing of knowledge management processes to an external entity (Perechuda, 2007, pp. 125-130; Dźwigoł, Wolniak, 2018, pp. 1114-1116). However, this approach has many opponents among top executives. Thus, will knowledge process outsourcing become a basis factor affecting the shape of the contemporary model of knowledge management? Advantages and disadvantages of the approach in question can be presented as follows:

Disadvantages of the process:

- doing away with a basic resource for the enterprise, that is with knowledge,

- in contemporary enterprises, knowledge management becomes a rudimentary process,

- outsourcing of core activities may result in the occurrence of a so-called "zeroing" of the enterprise internal structures. This may bring about the annihilation of the enterprise (demolition, termination of activity) (Minbaeva, 2007, pp. 567-593).

Advantages of the process (Dźwigoł, 2015b):

- releasing owners of enterprises from their obligation to deal with basic and ancillary processes,

- greater specialisation requires outsourcing some areas of the enterprise's activity (nowadays, it is difficult to achieve comprehensive knowledge in terms of a given discipline),

- virtualisation of business activity makes one transfer basic and ancillary activities to co-operators, in compliance with customers' various needs,

- keeping basic and ancillary processes within the parent company may, in the long term, turn out to be too costly,

- transferring basic processes to middle-size enterprises makes the enterprise's operation more flexible, as the bureaucratic machine is released from hierarchised arrangements and decisions (e.g. Airbus, Siemens, Philips).

Before making a decision pertaining to outsourcing of ancillary functions, it is necessary to assess the risk connected with losing some of the enterprise's operational qualities. It does not change the fact that outsourcing is a dynamic factor for the development of modern enterprises. One should bear in mind that corporation's consistency and operational qualities can be maintained by employing a proper strategy as regards a vision, mission and responsibility towards the environment. Within the scope of the knowledge-based economy, a basic factor determining the competitiveness does not just mean having productive resources at one's 
disposal, - it also involves being able to access and use them (Herman, 2003, p. 147). As far as knowledge management is concerned, one of its priorities involves establishing and making use of the banks of data and skills that every employee has at his/her disposal.

Intellectual organisations (Tkaczyk, 2003, pp. 44, 178) become especially important when competing with rivals, as the organisations are able to come up quickly with ingenious solutions, while the latter may be a reply to the conditions of the environment changed as a result of social and economic systems. A particular asset of the intellectual organisation encompasses effective knowledge management and abilities in terms of intellectual capital accumulation. Although knowledge is reflected in all aspects of the enterprise's activity, it is mainly used within the scope of organisation, technology and production (Grudzewski, Hejduk, 2002, p. 11).

R. Borowiecki holds the opinion that restructuring has recently become deeply rooted in the development of today enterprises. The need to introduce changes arises from the necessity to continuously improve effectiveness, while the requirement for permanent restructuring is a natural consequence of the information paradigm pertaining to the enterprise's activity (Borowiecki, 2003, p. 134). The paradigm in question manifests in the achievement of restructuring objectives, while the said objectives reflect themselves in enhanced competitiveness of the enterprise, improved adaptability and flexibility of the enterprise's activity, the finest possible integration of activities, as well as creation of a modern organisational culture along with innovative attitudes (Borowiecki, 2003, pp. 26-28). The importance of the informative resource area (which is one of elements of the organisational restructuring model) for the process of creating an intelligent organisation has been recognised by W.M. Grudzewski and I.K. Hejduk. The researchers maintain that the process of implementing intelligent enterprises into economic practice requires to develop, within the scope of organisation and management systems, communication based on IT networks of LAN type (Local Area Network), on intelligent terminals which create the Internet and use other databases (Grudzewski, Hejduk, 2004, p. 195). Activities, set forward within the scope of the organisational restructuring model, and pertaining to modelling of informative resources introduce modern and massive processing of data and information, in addition to application of expert systems in terms of production, marketing, sales and finances (e.g. integrated systems of production management). The said concept of informative system favours integration of all aspects of the enterprise's activity.

With reference to the foregoing, the model of organisational restructuring manifests in a preliminary stage of creating an intelligent organisation in compliance with the resource-based view (Grudzewski, Hejduk, 2004, p. 16) already known from the strategic management prospective. According to strategic management practices, knowledge hidden in the key abilities can provide the enterprise with a durable competitive advantage. In terms of changes, particularly important for setting foundations of an intellectual organisation is the reorientation of, e.g., hard coal mining companies towards task-based activities (project management 
method), supplemented by diversification of rigid organisational structures and opportunities pertaining to improved flexibility of employment as regards to the needs of the labour market.

\subsection{Organisational forms in the process of the enterprise's restructuring}

The globalisation of the world economy forces enterprises to introduce changes to management systems and rigid organisational structures to the benefit of more flexible ones. In today's world, single-plant enterprises are a basic legal and organisational form of conducting business activity. However, nowadays, the opportunities to develop organisations within their rudimentary scope of activity - i.e. focusing solely on a single business or national market - are exhausting (Pierścionek, 2011, pp. 297-298). The organisational structure and the form of the enterprise's activity that have been so far regarded as the most optimal, should evolve towards a transparent structure consisting of just a few hierarchical layers. In functional enterprises, there occurs a profound division of labour, whereas the processes, especially intrafunctional ones, are rarely the subject of interest. In contrast, process-oriented enterprises tend to depart from the fragmentary division of organisations, with the purpose of treating globally all activities covered by the processes taking place in particular organisational units (McCormack, Joh, 2006, p. 22).

Disadvantages of functional organisations (Nowosielski, 2007, pp. 155-157) include:

- monotony and its influence on performance and quality,

- within a determined function, there occur only the processes which are necessary for the fulfilment of a given function,

- lack of process identification,

- lack of ordered and systematic modelling, and of process management,

- lack of employees in charge of processes and process teams,

- process chains are broken by boundaries of functional areas (subsidiaries, 'departmentislands' of processes at different levels),

- managers fail to discern final results that are of importance to customers,

- emphasis is put on the interior of the organisation and not on customers - who determine the enterprise's further prosperity,

- the management is usually concentrated on the parts of the processes,

- there exists a real danger of blurring the responsibility for final results of the enterprise's activity.

Advantages of functional organisation (Dźwigoł, 2015b) are:

- use of top-class experts,

- use of specialist machines and appliances in particular functional divisions,

- improved quality,

- clear division of responsibilities,

- significant transparency. 
The process organisation is the highest form of organisational development, whereas internal organisational units are created on the basis of economic processes (Schmelzer, Sesselman, 2003, pp. 106-114).

Advantages of the process organisation include:

- lack of 'free economic spaces' within the enterprise,

- customer-oriented approach is reinforced within the whole enterprise,

- reduction of hierarchical links,

- flexible attitude towards changes,

- motivational system oriented to customers and process performance,

- specialisation means enhancing the process organisation's abilities, up to its multifunctionality.

Disadvantages of the process organisation are:

- less effective use of the enterprise's resources due to their fragmentation into processes,

- necessity to pursue time-consuming, horizontal coordination of the activity,

- the system cannot cover the whole activity of the enterprise,

- employment of additional staff may be required,

- access to resources and knowledge sharing are hindered.

\subsection{Mixed forms - matrix organisation}

This is a combination of elements typical for functional and process structures, which treats both dimensions equally. On the one hand, one can notice the customer-related approach, whereas, on the other hand, there exist function competencies. The process management requires taking into consideration the double subordination and plenitude of crossing points for functions and processes (Stoeger, 2005, p. 33). In the matrix (hybrid) organisation, one should take into account (Dźwigoł, 2015b):

- functional units which prepare resources for particular processes, and perform on them some determined services,

- responsibility for resources lies with managers of functional units,

- responsibility for process results lies with process managers,

- motivational system should be applied in case of a process manager and functional manager,

- the enterprise should be divided into responsibility centres (cost centres, profit centres),

- conflicts between functional cells and processes.

The application of process and hybrid organisations requires considerable promptness to introduce changes, and necessitates notably a shift in awareness and the enterprise's organisational culture. The employment of this type of organisation is particularly important in enterprises operating on the project-management basis. 
Considering the above-mentioned approaches pertaining to organisation modelling, one should bear in mind that in case of modelling of restructuring processes, the scope of the restructuring in question is outlined by specific restructuring objectives and ensuing scope of changes to be introduced in the enterprise, as well as general rules and method-related guidelines for the implementation of organisational changes. What is important here is to maintain an individual approach to every restructuring action, with the assumption that there is no single and universal model of restructuring process that would be useful for all enterprises and in all situations.

Considering the systems approach (which defines the organisation), one should focus on seven areas of the enterprise's activity, also defined as 'principal areas', which can be treated as the most essential frames for diagnosing. The key areas are the following (Dźwigoł, 2015b):

- marketing and sales area,

- production area,

- human resources area,

- tangible resources area,

- financial resources area,

- organisational resources area,

- informational resources area.

Consequently, the area mentioned above should be the basic elements of the modelling of the enterprise's activity within the scope of the restructuring process.

\section{The concept of the restructuring concept process on the example of hard coal mining enterprises}

\subsection{Consolidation of mining enterprises including enterprises from the environment}

The considerations related to the directions of organizational activities aimed at improving the effectiveness of mining enterprises were based on an analysis of the functioning of the hard coal mining sector.

The considerations concern the following issues (Dźwigoł, 2010. s. 130):

- Restructuring mining enterprises.

- Consolidation of mining enterprises, including enterprises from the environment.

- Privatization of mining enterprises. 
Two consolidation options are possible:

- merger by acquisition - transfer of all the assets of the taken-over company to another (acquiring) company for shares or stocks which the acquiring company issues to the partners of the acquired company,

- merger by establishment of a new company - establishment of a capital company to which the assets of all merging companies are transferred for shares in a new company.

Legal effects of merger registration include:

- acquisition by the acquiring company of all the rights of the company being acquired acquisition by the connecting company of the assets of the merged company,

- taking over by the acquiring company of the obligations incumbent on the company being acquired, including tax obligations and obligations arising from events that took place on the part of the company being acquired before the merger,

- general succession on the part of the acquiring company (they also pass permits and concessions, unless the concession decision provides otherwise).

The experience of mining enterprises related to merging mines confirms a significant decrease in the employed crew. The proposed concept will give further opportunities to increase the scope of technical restructuring of mines, e.g. the liquidation of further unnecessary shafts opens the possibility of obtaining additional resources trapped in these pillars, reduction of railway infrastructure, better and full possibilities of using the processing capacity of modern processing plants, more optimal time-spatial projection of mining works, rational drainage of underground waters and minimization of negative impacts on the environment, as well as disposal of unnecessary assets (buildings, structures and mining areas) (Pyka, 2004, p. 401-403).

\subsection{Basic consolidation criteria}

The consolidated company creates a complete and comprehensive customer service system based on diversified primary fuel sources. The created consolidated unit is a highly complex and unlimited area. This does not mean that organizational units combined according to the spatial and logistics criterion cannot be created within the consolidated group. This applies in particular to combined heat and power plants and heat distribution plants, as well as lignite mines and lignite power plants.

The concept should meet the criterion of compliance with the state's energy policy aimed at creating competitive units, as well as the criterion of energy security (Dźwigoł, DźwigołBarosz, Zhyvko, Miśkiewicz, Pushak, 2019, pp. 307-317). Only strong, consolidated entities have a chance to stay on the market. These units can afford modernization and development investments, and can also cooperate with energy giants operating on the EU integrated market (Dźwigoł, Aleinikova, Umanska, Shmygol, Pushak, 2019, pp. 1-7). 
The company consolidated under Model XIV is difficult to restructure due to its complexity. High inertia and resistance to change can be expected. It is also worth paying attention to the possibility of concealing malfunctions behind the facade of a large organization, where the results are averaged.

The value offered to recipients consists of:

- a wide range of proffered products and services,

- reliability and quality of deliveries and service efficiency,

- security of energy media supplies.

Thanks to owned resource base, added value is obtained in the following processes: Hard coal mining, - obtaining gas, as well as in the process of generating electricity and heat. Sample consolidation concept.

Model entities - the concept assumes the existence of many entities located at various levels of the value added chain. The power level consists of (Pyka, 2004, p. 401):

- hard coal mines,

- brown coal mines,

- group of hard coal mines.

The nature of connections - creating a concept in terms of connections between all phases of the value chain enables the isolation of subsequent links in the process from the acquisition of primary energy sources, through its conversion into electricity or heat and transmission through networks, up to sale to the final customer. This directional sequence of vertical dependencies in energy conversion logistics does not preclude horizontal relationships within individual industries.

In many proposed consolidation models in the fuel and energy sector, a system of connections between a brown coal mine and a brown coal power plant was identified. The geographical proximity of these entities and the technological link allow the display of this specific type of spatial and technological connections (Dźwigoł, Dźwigoł-Barosz, Zhyvko, Miśkiewicz, Pushak, 2019, pp. 307-317).

Management - the concept applies to a large capital group covering all separate phases in the energy sector. The management of such a large unit requires a reasonable shaping of the internal structure. A holding structure that groups companies around a particular distribution company seems to be a good solution.

The creation of an organization with horizontal relationships gives large effects resulting from the concentration of enterprise functions, such as joint marketing effort, joint research, and concentration of financial resources for investments. On the other hand, horizontally combined units according to industry logic are not very flexible. 
Key competences - the concept generates a need for various competences that create a barrier to entry into the sector. In mining processes, skills and knowledge of exploration and cutting of hard coal deposits, recognition and preparation of deposits for surface exploitation, safe and deep mining of hard coal deposits, and exploitation of gas deposits are necessary.

Ecological protection and compliance with environmental protection standards are important competences. Heaps, saline water, drainage, mining damage are just some of the threats to the natural environment. The production of electricity and heat from coal requires the solution of many technical and organizational problems, such as ecological burning of coal, the use of waste or its removal. The necessary competences are not limited to forms of obtaining energy sources and its processing (Pyka, 2004, pp. 401-405). The necessary competences in the area of distribution and marketing that condition efficient customer service are listed below. In particular, these are competences in the field of:

- distribution of electricity,

- heat distribution,

- gas distribution,

- trading in electricity,

- servicing corporate clients in the scope of energy and gas supplies,

- individual customer service (households),

- providing services to SMEs,

- risk management on the wholesale electricity market,

- purchase and sale of electricity on the stock exchange and balancing market.

\section{Material resources}

The group's basic wealth is natural resources (Pyka, 2004, pp. 401-415):

- hard and brown coal,

- gas.

Capital intensive technologies are required to obtain raw materials. Particularly large outlays should be incurred for the construction and equipment of deep coal mines. Also lignite mining and drainage equipment, excavators, loaders and conveyors make up the capitalconsuming technical equipment of mines.

Technical equipment for gas intakes complements the assets of resource extraction enterprises. Equipping with machines, devices, generating sets, transport means of power plants and combined heat and power plants is the third, valuable group of resources. The fourth group of resources are transmission and distribution networks: electricity, heat, gas.

Environmental protection devices also need to be dealt with separately. Their value increases with the tightening of environmental protection regulations. In the context of EU regulations, one should take into account the increase in expenditure on this type of resources. The development of internet service and integrated customer service will require 
extensive resources creating computer and telephone centers. Large financial and human capital outlay is necessary for the smooth functioning of the consolidated group. Staff with different qualifications is a resource that decides about the use of material resources. The total material resources of the consolidated group are supplemented by coal and gas reserves.

\section{Intangible resources}

These resources mainly form functional systems. Included are:

- deep coal mining systems,

- open-cast brown coal mining systems,

- gas extraction system,

- coal mining securing systems (drainage, methane drainage),

- environmental protection systems,

- cogeneration,

- electricity and heat distribution system,

- gas distribution system.

- network management system,

- network security systems,

- integrated customer service system,

- debt collection systems,

- employee selection and training systems,

- group management systems and procedures, including the financial system,

- motivating system,

- internal control system (audit).

Behind the functional systems there are resources of human knowledge and competences, as well as the experience necessary to run and supervise the mentioned systems.

The durability of the competitive advantage of the consolidated group according to Model $\mathrm{XIV}$ is ensured by:

- raw material resources,

- closing the value chain from obtaining raw materials to customer service.

\subsection{Directions of organizational changes under consolidation (Pyka, 2004, pp. 401-403)}

Hard coal mining consists of individual mines with very different characteristics, but in essence it is an economic organism that cannot function properly without a coherent, pro-effective investment policy implemented in the structures above mines; without a jointly maintained scientific and research base, ensuring the necessary progress in combating threats, in the development of technology and equipment, etc.; without own financial reserves enabling safe operations in conditions of high uncertainty. Hence, the economic and financial condition 
of coal companies and the entire coal mining industry will largely depend on the accuracy of the selection criteria for joining mines into larger economic organisms.

For strategic reasons, it also seems advisable to have a capital connection within the capital group of entities carrying out, e.g. coal sales. In addition, linkage beyond financial is necessary within the capital group of coal producers and entities selling coal that on the principles of dealership would implement a uniform marketing strategy integrated with uniform planning of the volume and quality of coal production depending on market needs. Moreover, the functioning of specialized plants (commercial law companies), e.g. those dealing with accounting services for coal concerns and handling logistics processes of concerns, should be included in such a mining structure.

\subsection{The effects of creating a new organizational structure (Pyka, 2004, pp. 401-415)}

As part of the new structure, the privatization process of non-productive assets of mines will be continued, on the basis of which economic entities are created that are aimed at becoming independent from the mining sector and entering external markets.

Mining enterprises will be able to develop a uniform and rational policy of reducing employment in mines based more on the principle of moving the best experienced staff between mines and creating new jobs generated by the joint effort of mines and municipalities.

The creation of a large economic organism will shape the conditions and social climate conducive to the creation of an adequate number of jobs within the mining enterprise.

In particular, remediation and development of areas devastated by existing mining activities provides great opportunities. The implementation of these tasks as part of a coal group, using its facilities for this purpose (as a separate plant or commercial law company) will also quite easily attract external investment capital (Dźwigoł, Aleinikova, Umanska, Shmygol, Pushak, 2019, pp. 1-7). The possibility also exists of separating specialized plants within the group whose activity would be based on the ongoing liquidation of the effects of mining operations, the so-called mining damage.

From the point of view of creating new jobs, there is also an ecological aspect to coal production. A large field of activity in this sectort is carried by the entire sphere of post-flotation waste management, which, thanks to the use of modern technologies, can be an excellent component of proppant mixtures, material for the production of prefabricated building materials, or material used in road construction. The economic use of rich methane resources can be another direction.

These types of projects, in addition to scientific support, require adequate funds to finance investments, but the use of such opportunities by the capital with a strong coal concern with the participation of external financing sources (European Union funds, budget funds) will definitely change the strategy of employment restructuring in the mining industry (from passive to active) in terms of creating new jobs, and, at the same time, may turn out to be the realization of the 
"ecologist's dream" of full recycling and the economist's dream of obtaining the product at the lowest cost, in this particular case - from waste.

As part of a strong capital group, the coal industry should also consider the possibility of starting a banking or property and personal insurance business.

In terms of current opportunities to implement research challenges (Pyka, 2004, pp. 401-403), the following are suggested:

- realization of research challenges requires undertaking systemic measures on the scale of the entire economy, as well as local ones in the area of mining. System solutions must create mechanisms for a situation of mutual interest in innovative solutions. The entrepreneur (e.g. mine) should have specific financial preferences that would constitute a kind of bonus for the striving to implement innovative progress in the enterprise. It seems necessary to create special funds at the state level that can support innovative activity on specific, preferential conditions.

- solutions that can be shaped within the hard coal mining industry require a determined pursuit by scientific and research units and mining entrepreneurs to create real and significant innovative progress and adequate research challenges for it.

In the scope of consolidation and privatization:

- the enterprise will have large assets, and thus its market value will be very high. This creates opportunities for cheap acquisition of external power both in financial capital and working capital.

- the company will have a strong competitive position in all offered products. This results from the possessed competences, but also from huge assets and the possibility of concentration of accumulated own and external resources for investments and innovations.

- by diversifying production - electricity, heat, gas, water and other complementary services - the company reduces market risk.

- a transparent organizational structure built on the principles of individual responsibility will enable decentralization of management and improvement of its effectiveness and efficiency.

- concentrating strategic decisions in one decision center will enable implementing the principle of uniform management within the whole group of enterprises.

- increasing the efficiency of using coal resources, uniform grouping of enterprises, rational, selective deposit management, as well as increased investment opportunities and comprehensive modernization of mine technical equipment will ensure greater profitability. 
- increasing the ability to meet market needs in terms of quality and product range, and increasing flexibility in responding to market changes will enhance the success of the enterpise as a whole.

- improving the efficiency of coal distribution, strategic market management, segmentation of the coal market and optimal use of distribution channels of coal sales centers will generate greater profitability.

Meeting the challenges posed to Polish hard coal mining requires above all a systematic approach to solving the basic organizational problems of the sector and a thorough reconstruction of all economic and social relations. The sector restructuring processes will be as effective and efficient as the corresponding changes in the management system and organizational structures that it corresponds to. The proposed organizational structure is optimal from the point of view of achieving a balance between social protection and competitiveness within a flexible enterprise with programmed ability to change (Pyka, 2004, pp. 401-415).

\section{Summary}

In the modern world, objectives of the enterprise must be more comprehensive, and thus we face an evolution of the enterprise that is aimed at automatisation and flexibility (Bąk, 2009). With reference to the foregoing, the diagnosis is the starting point to formulate strategies for the enterprise's development. Therefore, the diagnosis should be carried out by interdisciplinary teams that consist of competent professionals and experienced practitioners selected among and beyond the enterprise's specialists. It is essential to invite to the teams those specialists who boast wide experience in organising and managing, as well as expertise in other disciplines needed for establishing the said diagnosis. In this case, management and leadership must attempt to meet a series of conditions so as to make possible the fulfilment of goals in the most effective way. Relationship between management and leadership is of key importance here. It is necessary that every organisation knows what tasks should be performed by its manager, what responsibilities should be assigned to its leader, and what should be the common area for both roles (Koźmiński, Jemielniak, 2011, p. 21).

It is not possible to create a single restructuring model that would be suitable for every enterprise. While preparing a restructuring programme, although one uses similar operating rules, more detailed solutions depend on the specific character of the enterprise in question. Questions pertaining to anticipated dimensions of restructuring and scope of business activity to be affected all depend on the kind and influence of the factors that triggered the process in question, as well as on the restructuring goal. The restructuring process can cover the whole enterprise or its greater part. One cannot forget that restructuring is a comprehensive and continuous process, designed to restore, maintain or improve the enterprise's competitive 
advantage on the market (Dźwigoł, 2015b). Continuous restructuring is now a natural consequence of managing every modern enterprise in order to restore its internal balance and balance with the environment (Dźwigoł, 2011, p. 190).

\section{References}

1. Bąk, E. (2009). Nietypowe formy zatrudnienia na rynku pracy. Warszawa: C.H. Beck.

2. Borowiecki, R. (2003). Restrukturyzacja narzędziem wykorzystywania potencjalnych możliwości gospodarki opartej na wiedzy. In: Przedsiębiorstwo przyszłości - nowe paradygmaty zarządzania europejskiego. Książka poświęcona 50-leciu Instytutu Organizacji i Zarzadzania w Przemyśle ORGMASZ. Warszawa: ORGMASZ.

3. Carpenter, M.A., and Sanders, W.G. (2007). Strategic Management. A Dynamic Perspective: Concepts and Casus. Upper Saddle River: Pearson Prentice Hall.

4. Cyfert, Sz. (2006). Strategiczne doskonalenie architektury procesów w zarządzaniu przedsiębiorstwem. Poznań: Wydawnictwo Akademii Ekonomicznej.

5. De Wit, B., and Meyer, R. (2007). Synteza strategii. Tworzenie przewagi konkurencyjnej przez analizowanie paradoksów. Warszawa: PWE.

6. Dźwigoł, H. (2007). Diagnosis of production enterprise organizational system. In: J. Lewandowski, and I. Jałmużna (eds.), Process Management in Production Systems. Łódź: Wydawnictwo Politechniki Łódzkiej.

7. Dźwigoł, H. (2010). Podejście systemowe w procesie restrukturyzacji przedsiębiorstwa. Gliwice: Wydawnictwo Politechniki Śląskiej.

8. Dźwigoł, H. (2011). Controlling w procesie zarządzania współczesnym przedsiębiorstwem. Gliwice: Wydawnictwo Politechniki Śląskiej.

9. Dźwigoł, H. (2013). Zarządzanie przedsiębiorstwem $w$ warunkach XXI wieku. Gliwice: Wydawnictwo Politechniki Śląskiej.

10. Dźwigoł, H. (2014). Unternehmensmanagement im 21. Jahrhundert. Borsdorf: Edition Winterwork.

11. Dźwigoł, H. (2015a). Bussiness Management. India: Narosa Publishing House.

12. Dźwigoł, H. (2015b). Bussiness Management. Oxford, UK: Alpha Science International Ltd.

13. Dźwigoł, H., Aleinikova, O., Umanska, Y., Shmygol, N., \& Pushak, Y. (2019). An Entrepreneurship Model for Assessing the Investment Attractiveness of Regions. Journal of Entrepreneurship Education, 22(SI1), 1-7.

14. Dźwigoł, H., Wolniak, R. (2018). Controlling w procesie zarządzania chemicznym przedsiębiorstwem produkcyjnym [Controlling in the management process of a chemical 
industry production company]. Przemyst Chemiczny, 97(7), 1114-1116. https://doi.org/ 10.15199/62.2018.7.15.

15. Dźwigoł, H., Dźwigoł-Barosz, M., Zhyvko, Z., Miśkiewicz, R., Pushak, H. (2019). Evaluation of the energy security as a component of national security of the country. Journal of Security and Sustainability Issues, 8(3), 307-317. http://doi.org/10.9770/ jssi.2019.8.3(2).

16. Groble, A. (2006). Metodologia nauk. Kraków: Wydawnictwo Aureus i Wydawnictwo Znak.

17. Grudzewski, W.M., Hejduk, I.K. (2002). Przedsiębiorstwo intelektualne. Warszawa: Difin.

18. Grudzewski, W.M., Hejduk, I.K. (2004). Systemy zarządzania wiedzą - nowy paradygmat czy wyzwanie? In: I.K. Hejduk (ed.), Przedsiębiorstwo przyszłości - funkcje i rzeczywistość. Warszawa: ORGMASZ.

19. Hamel, G., Valikangas, L. (2003). W poszukiwaniu zdolności strategicznej regeneracji. Harvard Business Review/Polska, XI, Nov.

20. Herman, A. (2003). Zarządzanie wartością przedsiębiorstwa w gospodarce opartej na wiedzy. In Przedsiębiorstwo przyszłości - nowe paradygmaty zarządzania europejskiego. Książka poświęcona 50-leciu Instytutu Organizacji i Zarządzania w Przemyśle ORGMASZ. Warszawa: ORGMASZ.

21. http://www.egov.p1/index2.php?option=content\&do_pdf=1\&id=84, 12.04.2004.

22. https://www.scopus.com/authid/detail.uri?authorId=57207952997.

23. Jashapara, A. (2006). Zarzadzanie wiedza. Warszawa: PWE.

24. Kobyłko, G., Morawski, M. (2006). Przedsiębiorstwo zorientowane na wiedzę. Warszawa: Difin.

25. Koźmiński, K.A., Jemielniak, D. (2011). Zarządzanie od podstaw. Warszawa: Oficyna Wolters Kluwer Business.

26. Krzakiewicz, K. (2007). Od organizacji uczącej się do organizacji intelektualnej. In: Współczesne kierunki nauk o zarządzaniu. Księga jubileuszowa z okazji 50-lecia pracy naukowej i dydaktycznej Profesora Jerzego Rokity. Katowice: Górnośląska Wyższa Szkoła Handlowa.

27. McCormack, K.P., Joh, W.C. (2001). Business Process Orientation. London: St. Luce Press.

28. Minbaeva, D.B. (2007). Knowledge Transfer In Multinational Corporation. Management International Review, 47.

29. Nielsen, B.B., Michailova, S. (2007). Knowledge Management Systems In Multinational Corporation: Typology and Transitional Dynamics. Long Range Planning, 40.

30. Nowosielski, S. (2007). Od organizacji funkcjonalnej do organizacji procesowej. In: J. Pyka (ed.), Nowoczesność przemystu iusług. Procesy restrukturyzacji $i$ konkurencyjność w przemyśle i ustugach. Katowice: TNOiK. 
31. Perechuda, K. (2007). Outsourcing wiedzy II. Modele problemowe. In: Wspótczesne kierunki nauk o zarzadzaniu. Księa jubileuszowa z okazji 50-lecia pracy naukowej $i$ dydaktycznej Profesora Jerzego Rokity. Katowice: Górnośląska Wyższa Szkoła Handlowa.

32. Pierścionek, Z. (2011). Zarządzanie strategiczne w przedsiębiorstwie. Warszawa: PWN.

33. Pyka, J. (2004). Model XIV - Przedsiębiorstwo multienergy i multiutility o pełnym łańcuchu wartości i zdywersyfikowanych źródłach energii. In: J. Pyka (ed.), Koncepcje $i$ modele konsolidacji przedsiębiorstw w sektorze paliwowo-energetycznym. Prace naukowe Akademii Ekonomicznej im. Karola Adamieckiego w Katowicach.

34. Rokita, J. (2006). Dylematy stojące przed zarządzaniem strategicznym. In: J. Rokita, and W. Grudzewski (eds.), Strategie korporacji działajacych $w$ skali ponadnarodowej. Katowice: GWSH.

35. Rolet, H. (2003). Knowledge Management: Processes and Technologies. Boston: Kluwer Ac. Publisher.

36. Romanowska, M. (2007). Ewolucja myślenia strategicznego. In: Dynamika zarzadzania organizacjami. Paradygmaty - Metody - Zastosowania. Księga pamiatkowa wydana z okazji 50-lecia pracy naukowej prof. zw. dr hab. Jerzego Rokity. Prace naukowe Akademii Ekonomicznej im. Karola Adamieckiego w Katowicach. Katowice.

37. Schmelzer, H.J., Sesselman, W. (2003). Geschaftsprozessmanagement In der Praxis. Wien: Hanser.

38. Slyvotzky, J.A. (2000). Strefa zysku. Strategiczne modele działalności. Warszawa: PWE.

39. Sobczak, A., Strojny, M. (2004). Zarządzanie wiedza jako czynnik zwiększania konkurencyjności organizacji gospodarczych. Warszawa: PWE.

40. Stoeger, R. (2005). Geschaefts prozesse erabeiten-gestalten-nutzen. Stuttgart: SchaefferPoeschel Verlag.

41. Sudoł, S. (2006). Przedsiębiorstwo. Podstawy nauki o przedsiębiorstwie. Zarzadzanie przedsiębiorstwem. Warszawa: PWE.

42. Sudoł, S. (2007). Badania naukowe w zakresie zarządzania. In: Dynamika zarzadzania organizacjami. Paradygmaty - metody - zastosowania. Księga pamiątkowa wydana z okazji 50-lecia pracy naukowej prof. zw. dr hab. Jerzego Rokity. Prace naukowe Akademii Ekonomicznej im. Karola Adamieckiego w Katowicach. Katowice.

43. Tkaczyk, S. (2003). Paradygmaty i trendy w zarządzaniu opartym o kryterium jakości. In: Przedsiębiorstwo przyszłości - nowe paradygmaty zarządzania europejskiego. Książka poświęcona 50-leciu Instytutu Organizacji i Zarządzania w Przemyśle ORGMASZ. Warszawa: ORGMASZ.

44. Trout, J. (2005). Trout o strategii. Warszawa: PWE. 